\title{
Comparison of Cell Viability and Chemical Composition of Six Latest Generation Orthodontic Wires
}

\author{
Lina M. Escobar $\mathbb{D D}^{1,2}$ Jaime Rodrigo Rivera $\left(\mathbb{D},{ }^{2}\right.$ Eliana Arbelaez, ${ }^{2}$ Luisa F. Torres, ${ }^{2}$ \\ Andrea Villafañe, ${ }^{2}$ David Díaz-Báez $\mathbb{D}^{\mathrm{D}},{ }^{3}$ Ingrid Mora $\mathbb{D}^{3},{ }^{3}$ Gloria I. Lafaurie $\mathbb{D}^{4},{ }^{4}$ \\ and Midori Tanaka $\mathbb{D D}^{1,2}$ \\ ${ }^{1}$ Unidad de Manejo Integral de Malformaciones Craneofaciales UMIMC, Universidad El Bosque, Bogotá, Colombia \\ ${ }^{2}$ Posgrado de Ortodoncia, Facultad de Odontología, Universidad El Bosque, Bogotá, Colombia \\ ${ }^{3}$ Unidad de Investigaciones, Facultad de Odontología, Universidad El Bosque, Bogotá, Colombia \\ ${ }^{4}$ Unidad de Investigación Básica Oral UIBO, Universidad El Bosque, Bogotá, Colombia \\ Correspondence should be addressed to Lina M. Escobar; linaescobar10@gmail.com
}

Received 30 September 2020; Revised 14 December 2020; Accepted 16 January 2021; Published 28 January 2021

Academic Editor: Vijaya Kumar Rangari

Copyright ( 2021 Lina M. Escobar et al. This is an open access article distributed under the Creative Commons Attribution License, which permits unrestricted use, distribution, and reproduction in any medium, provided the original work is properly cited.

Orthodontic wires are made of alloys containing different metals, including nickel. It is important to evaluate their biocompatibility prior to use, owing to their long-term use in patients. This in vitro study compared the cytotoxicity and chemical composition of six latest orthodontic wires: Fantasia ${ }^{\circledR}$, Tanzo $^{\circledR}$, FLI $^{\circledR}, \mathrm{NT}^{\circledR}{ }^{\circledR}$, DuoForce ${ }^{\circledR}$, and Gummetal ${ }^{\circledR}$. The before-use group consisted of wires that were not used in the mouth, and the after-use group consisted of wires that were used in the mouth for two months. The wires were placed in contact with human gingival fibroblasts (HGF) for $72 \mathrm{~h}$, and cytotoxicity was determined using the resazurin test. The chemical composition and surface characterisation were evaluated by spectrometry and scanning electron microscopy. The groups were compared using ANOVA and Kruskal-Wallis test. Only the FLI ${ }^{\circledR}$ wires produced a $36 \%$ reduction in HGF viability $(p<0.05)$ and presented greater irregularities and loss of polymer structure. After-use wires showed a significant reduction in the percentage of nickel and the appearance of new elements (oxygen and carbon). Therefore, it can be concluded that no toxic ion release was noticed in this study. Rhodium-coated wires were more stable than PTFE-coated wires, and only the FLI ${ }^{\circledR}$ wires showed a slight cytotoxic effect.

\section{Introduction}

Currently, several types of wires with various metal alloys are used in orthodontic treatment. Fixed orthodontic wires are made of stainless steel (SS) and nickel-titanium (NiTi), which consists of chromium, cobalt, nickel, and titanium [1]. The oral cavity has chemical and microbiological conditions conducive to the release of metal ions from alloys and coatings [2]. These conditions include the alkaline properties of saliva, electrolytes formed by food debris, variations in $\mathrm{pH}$, mechanical action, and microbial flora [3]. Some of these released metallic elements can modulate the immune response causing inflammation [4], allergic and systemic reactions [5], and hypersensitivity [6]. Apart from allergic reactions, the release of ions may even cause cytotoxic effects, mutagenesis, and carcinogenesis [7]. There are great concerns regarding the biocompatibility of orthodontic wires and the ions related to their potential toxicity. It is a critical issue because of their long-term contact with the oral mucosa and the potential corrosion of different materials [8]. When choosing an orthodontic wire, it is important to have substantial knowledge of its composition, allergenic properties, and toxic effects. Additionally, a safety evaluation is required to consider the increasing variability of materials, their composition, and manufacturing processes since most orthodontists purchase materials that are commercially available without any concerns about their biocompatibility.

Among many alloys with shape memory materials, those with $\mathrm{NiTi}$ are the first choice of orthodontists because of their mechanical stability and biofunctionality [9]. 
Currently, there are several innovative $\mathrm{Ni}$-Ti orthodontic arches available, offering orthodontists a variety of choices. Some of these new wires are superelastic nickel-titanium, nickel-titanium-copper, titanium-niobium, and nickel-titanium wires with rhodium or polytetrafluoroethylene coating.

The superelastic nickel-titanium wire is highly resistant to permanent deformation, presents consistent loading and unloading forces, and has a highly polished surface [10].

On the contrary, the new copper-nickel-titanium wires, according to the manufacturer, maintains consistent loading and unloading forces so that the arch provides the same predictable performance every time, allowing the arches to work in the mouth for longer intervals. They are highly polished, which reduces friction and the accumulation of debris [11]. The addition of copper to the nickel-titanium alloy improves the thermal properties of the wire while still allowing the force to be controlled. It is resistant to permanent deformation and temperature progression [11].

In copper-nickel-titanium thermoactivated orthodontic arch, copper provides less force than a nickel-titanium arch. It also has two different strength zones, making it possible to use arches of a rectangular section from the first phases of the treatment, thus performing faster three-dimensional control [12].

There is an increased demand for aesthetic components in orthodontics treatments; therefore, coated wires with an epoxy resin polytetrafluoroethylene (Teflon) or rhodium have been developed. These wires coated with rhodium have low reflectivity, which is promoted as being less visible and improving aesthetics, and the coating also resists peeling or cracking of the aesthetic layer [13]. The wires coated with polytetrafluoroethylene (PTFE or Teflon) have been found to be nonreactive, noncorrosive, and resistant to flaking. In addition, it has a low friction level during treatment [14].

Finally, the beta-titanium alloy combines a low-value elastic modulus with extremely high hardness. The elemental composition of this alloy is titanium-niobiumtantalum-zirconium [9]. Among its features are superelasticity, easy control of orthodontic strength, plastic deformation without any distortion, and low friction. In addition, because heavy metals do not contain heavy metals, they do not induce toxicity [9].

Since these wires have been recently commercialised, there is little evidence in the literature regarding their biocompatibility in the oral cavity and changes in their chemical composition due to their use in the mouth. Therefore, this study aimed to determine and compare the chemical composition of six latest generation orthodontic wires and evaluate their effect on the viability of human gingival fibroblasts in vitro.

\section{Materials and Methods}

2.1. Test Materials. This is an experimental in vitro and riskfree study, in which six recently marketed orthodontic wires were selected: Fantasia Wire ${ }^{\circledR}$ (International Orthodontics Services IOS, Stafford VA, USA), Tanzo ${ }^{\circledR}$ (American Orthodontics AO, Sheboygan WI, USA), FLI ${ }^{\circledR}$ (Rocky
Mountain Orthodontics RMO, Denver CO, USA), NT3 ${ }^{\circledR}$ (American Orthodontics AO, Sheboygan WI, USA), DuoForce $^{\circledR} \quad$ (Forestadent Pforzheim, Germany), and Gummetal ${ }^{\circledR}$ (Rocky Mountain Orthodontics RMO, Denver CO, USA) (Table 1). These wires were used during the first two months of orthodontic treatment, and once discarded, their chemical composition and cytotoxicity were analysed.

2.2. Collection and Storage of the Sample. Six different types of wires were collected from private clinics. For disinfection, the obtained wires were immersed in $0.5 \%$ enzymatic soap Bonzime (Laboratorios Eufar S.A, Bogotá Co.) for $5 \mathrm{~min}$, washed with water, and kept in $2 \%$ glutaraldehyde (SigmaAldrich, Wuhan, China) for $3 \mathrm{~h}$. Finally, they were rewashed with water, dried with paper towels, and stored in separate bags that were labelled with the type of alloy, size, number of samples, and date.

2.3. Cytotoxicity Test. Primary gingival fibroblasts, obtained from a human adult (HGF) (ATCC ${ }^{\circledR}$ PCS-201-018 ${ }^{\mathrm{TM}}$ ), were used. The cells were seeded at 50000 cells/well in 24-well plates. They were maintained in Dulbecco's modified Eagle's medium (DMEM), supplemented with $10 \%$ foetal calf serum (FCS) and $1 \%$ penicillin/streptomycin and incubated at $37^{\circ} \mathrm{C}$ in a humidified $5 \% \mathrm{CO}_{2}$ atmosphere for $72 \mathrm{~h}$ according to ISO 10993-5 standards [15], until they reached approximately $80 \%$ confluency.

The wires were divided into two groups. The before-use group included wires that had not been used in the mouth and the after-use group included wires that had been used for two months. In total, 90 wires were evaluated: 30 wires in the before-use group ( 5 cuts of each wire) and 60 wires in the after-use group (10 for each type of wire). Different numbers of wires were used in each group because before-group wires were understood as control specimens that had minimal variability in controlled laboratory conditions. As a negative control of cytotoxicity, cells without exposure to any wire were used, and as a positive control, HGF was treated with Triton X-100 (Sigma-Aldrich, St. Louis, MO). The wires were cut into $1-\mathrm{cm}$ pieces and placed in contact with HGF for $72 \mathrm{~h}$, as previously reported [7]. Subsequently, cytotoxicity was determined using the fluorometric resazurin test. After $72 \mathrm{~h}$ of placing the wires on the cells, the culture medium was extracted, and the wells were washed with phosphatebuffered saline (PBS). Subsequently, $400 \mu \mathrm{L}$ of DMEM medium without supplementation with $10 \%$ resazurin $(\mathrm{v} / \mathrm{v})$ starting from an initial solution of $44 \mu \mathrm{M}$ (Sigma-Aldrich, MO, USA) was added per well and incubated for $4 \mathrm{~h}$ under standard conditions to allow for the reduction of resazurin to resorufin [16]. At the end of the incubation period, the plates were read at excitation and emission wavelengths of $535 \mathrm{~nm}$ and $595 \mathrm{~nm}$, respectively, in a microplate reader (Infinite 200 PRO Tecan Männedorf, Switzerland).

Since only metabolically active cells can cause this reduction, the amount of resorufin in each well was directly proportional to the number of viable cells present. Cell viability was then scored according to the classification of Ahrari et al. [17], as follows: more than $90 \%$ cell viability, no 
TABle 1: Archwires used in the study.

\begin{tabular}{|c|c|c|c|}
\hline $\begin{array}{l}\text { Orthodontic } \\
\text { wires }\end{array}$ & Manufactured by & Alloy & $\begin{array}{c}\text { Chemical } \\
\text { composition }\end{array}$ \\
\hline NT3 & American orthodontics $\left(\mathrm{AO}^{\circledR}\right)$ & Nickel-titanium & $\begin{array}{l}45.6 \% \mathrm{Ti} \\
54.6 \% \mathrm{Ni}\end{array}$ \\
\hline Tanzo & American orthodontics $\left(\mathrm{AO}^{\circledR}\right)$ & Nickel-titanium-copper & $\begin{array}{l}45 \% \mathrm{Ti} \\
49 \% \mathrm{Ni} \\
6 \% \mathrm{Cu} \\
\end{array}$ \\
\hline DuoForce & Forestadent ${ }^{\circledR}$ & Nickel-titanium-copper & $\begin{array}{c}44,6 \% \mathrm{Ti} \\
49,4 \% \mathrm{Ni} \\
6 \% \mathrm{Cu} \\
\end{array}$ \\
\hline FLI & Rocky mountain orthodontics $\left(\mathrm{RMO}^{\circledR}\right)$ & $\begin{array}{l}\text { Polytetrafluoroethylene (Teflon) PTFE-coated copper-nickel- } \\
\text { titanium }\end{array}$ & $\begin{array}{c}35,9 \% \mathrm{Ti} \\
54 \% \mathrm{Ni} \\
16 \% \mathrm{O} \\
0,9 \% \mathrm{Al} \\
3,3 \% \mathrm{Si} \\
11,5 \% \mathrm{C}\end{array}$ \\
\hline Gummetal & Rocky mountain orthodontics $\left(\mathrm{RMO}^{\circledR}\right)$ & Titanium-niobium & $\begin{array}{c}59,2 \% \mathrm{Ti} \\
34,1 \% \mathrm{Nb} \\
8,1 \% \mathrm{O}\end{array}$ \\
\hline Fantasia & $\begin{array}{l}\text { International orthodontics services } \\
\qquad\left(\operatorname{IOS}^{\circledR}\right)\end{array}$ & Rhodium-coated nickel-titanium & $\begin{array}{c}29 \% \mathrm{Ti} \\
53,6 \% \mathrm{Ni} \\
10 \% \mathrm{Rh} \\
6,7 \% \mathrm{Pd}\end{array}$ \\
\hline
\end{tabular}

cytotoxicity (none); 60\%-90\% cell viability, slight cytotoxicity; $30 \%-59 \%$ cell viability, moderate cytotoxicity; and less than $30 \%$ cell viability, severe cytotoxicity.

\subsection{Evaluation of the Chemical Composition and Surface} Changes of the Wires. An analysis of the surface degradation of the wires was performed using scanning electron microscopy (SEM) equipped with energy dispersive spectroscopy (EDS) for the quantification of X-ray photons (JEOL - JSM-6490LV Peabody MA, USA). The changes in its chemical composition were determined through fluorescence spectrometry with EDS of each element present in the wires. Each section of all wires was analysed, and the final semiquantitative chemical composition corresponded to the average given by the chemical analysis software with correction type $\mathrm{ZAF}$ ( $Z=$ fluorescence), yielding percentage values of the atomic weight of each element present in the wires.

2.5. Statistical Analysis. The data was subjected to statistical interpretation by analysis of variance (ANOVA) for parametric data and the Kruskal-Wallis test for nonparametric data in the analysis of the comparison between groups. The normality of data distribution was tested using the Shapiro-Wilks test.

The Mann-Whitney test was used to determine which pairs of groups differed significantly from each other. The type 1 error rate was adjusted using Bonferroni correction. A comparison of the cytotoxic effect and chemical composition data for each type of wire in both groups (before and afteruse) was performed using a paired $t$-test or Wilcoxon signed-rank test according to the distribution of the data.
The analysis was carried out using the statistical package STATA (Statistical software: Release 14. College Station, StataCorp Cary, NC, USA). The data obtained by X-ray scattering spectroscopy (EDS) were analysed using the statistical program $R$ (version 3.0.3, 2014, Chile). A $p<0.05$ was considered statistically significant.

\section{Results}

3.1. Cytotoxic Effects of the Orthodontic Wires. All the wires studied showed a minimal reduction in the viability percentages when the number of live cells was compared before and after use in the mouth. The percentages of cytotoxicity for NT3 ${ }^{\circledR}$, Tanzo ${ }^{\circledR}$, DuoForce ${ }^{\circledR}$, Gummetal ${ }^{\circledR}$, and Fantasia ${ }^{\circledR}$ were $15 \%, 8 \%, 1 \%, 2 \%$, and $12 \%$, respectively. However, this reduction in viability was not statistically significant $(p>0.05)$. Only the FLI ${ }^{\circledR}$ wires showed a cytotoxic effect of $36 \%$, which was statistically significant and corresponded to slight cytotoxicity (Figure 1 and Table 2).

3.2. Changes in Chemical Composition. When evaluating the changes in the chemical composition of the six wires, an increase in carbon $(\mathrm{C})$ was found in $\mathrm{NT} 3^{\circledR}$ wires, ranging from $1.7 \%$ in the before-use group to $18.5 \%$ in the after-use group. In the same group of wires, a reduction of titanium (Ti) and nickel $(\mathrm{Ni})$ was observed, and $6.2 \%$ of oxygen $(\mathrm{O})$ appeared in the after-use group (Figure $2(\mathrm{a})$ ). Tanzo ${ }^{\circledR}$ wires also presented a reduction of $20 \%$ in $\mathrm{Ni}$ and $\mathrm{Ti}$ and an appearance of $\mathrm{C}(15 \%)$ and $\mathrm{O}(5 \%)$ in the after-use group (Figure 2(b)). In DuoForce ${ }^{\circledR}$ wires, $\mathrm{Ni}$ and $\mathrm{Ti}$ reduction was determined, similar to that found in the NT3 ${ }^{\circledR}$ and Tanzo ${ }^{\circledR}$ wires. Elements $\mathrm{C}(19.6 \%)$ and $\mathrm{O}(6.6 \%)$ appeared while 


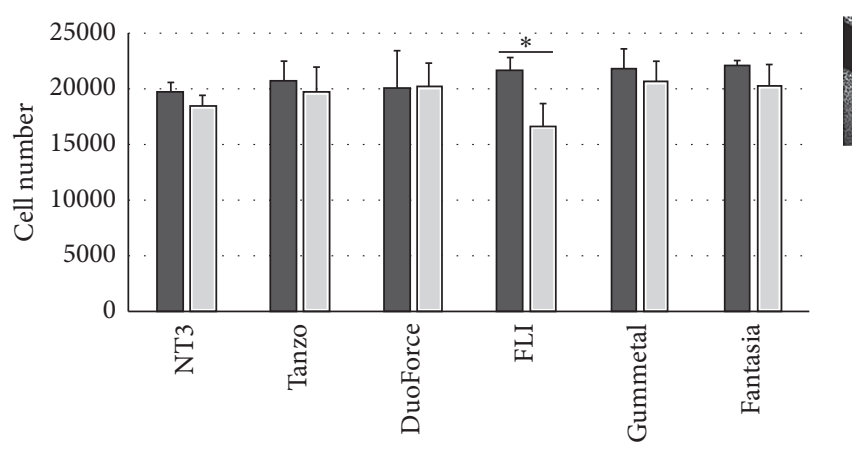

Before use After use
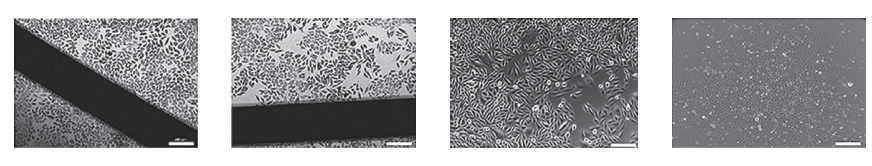

(a)

(b)

(c)

(d)

(e)

FIgURE 1: Cell viability (a). Number of fibroblasts obtained after cell culture with each type of wire, before or after use in the mouth. The FLI wire was the only one that produced a significant reduction in cell viability after use in the mouth $\left({ }^{*} p \leq 0.05\right)$. Photomicrographs of human gingival fibroblasts: HGF were observed in contact $(72 \mathrm{~h})$ with the NT3 wire before (b) and after use (c) in the mouth. Similar images were obtained with the other wires studied. The positive viability control corresponded to cells without contact with the wire (d), and the negative viability control was cells treated with Triton X-100 (e). Bar: $200 \mathrm{~mm}$.

TABLE 2: Number of living-HGF cells exposed to different wires, before and after being used in the mouth, and percentage of cytotoxicity after $72 \mathrm{~h}$.

\begin{tabular}{|c|c|c|c|c|}
\hline Orthodontic wires & $\begin{array}{r}\text { Before-use group } \\
\text { Live }\end{array}$ & $\begin{array}{l}\text { After-use group } \\
\text { SD }\end{array}$ & Cytotoxicity (\%) & $p$ value \\
\hline NT3 & $19719 \pm 852$ & $18506 \pm 891$ & 15 & NS \\
\hline Tanzo & $20838 \pm 1633$ & $19699 \pm 2314$ & 8 & NS \\
\hline DuoForce & $20127 \pm 3320$ & $20242 \pm 2051$ & 1 & NS \\
\hline FLI & $21771 \pm 1016$ & $16710 \pm 1932$ & 36 & $p \leq 0.05^{*}$ \\
\hline Gummetal & $21865 \pm 1683$ & $20734 \pm 1686$ & 2 & NS \\
\hline Fantasia & $22132 \pm 394$ & $20379 \pm 1796$ & 12 & NS \\
\hline
\end{tabular}

${ }^{*} t$-test was used for statistical significance. NS: nonsignificant.

phosphorus $(\mathrm{P})$, sulphur $(\mathrm{S})$, and silicon $(\mathrm{Si})$ were found in low proportions in the after-use group (Figure 2(c)).

On the contrary, $\mathrm{FLI}^{\circledR}$ arches showed an increase in $\mathrm{C}$ from $11.5 \%$ (before-use group) to $23.3 \%$ (after-use group). Additionally, a significant reduction was observed in $\mathrm{Ni}, \mathrm{Si}$, $\mathrm{O}$, and Ti (Figure 2(d)).

Gummetal ${ }^{\circledR}$ arches presented a significant increase in C (from $5.5 \%$ to $25.5 \%$ ) and $\mathrm{O}$ (from $8.1 \%$ to $14.4 \%$ ), and reduction in niobium $(\mathrm{Nb})$ and $\mathrm{Ti}$ in the after-use group (Figure 2(e)). In the Fantasia ${ }^{\circledR}$ arches, there was a reduction in $\mathrm{Ni}(44 \%)$, palladium $(\mathrm{Pd})(1.1 \%)$, and rhodium (Rh) (3.2\%). C and $\mathrm{O}$ appeared, and only $\mathrm{Ti}$ was increased to $33.1 \%$ in the after-use group (Figure $2(\mathrm{f})$ ).

3.3. Wire Surface Alterations. Parallel lines, cracks, and wells were observed in the before-use group. These were deeper in the after-use group. Additionally, dark areas compatible with food debris or bacterial plaque were observed in NT3 ${ }^{\circledR}$ (Figure 3(a)), Tanzo ${ }^{\circledR}$ (Figure 3(b)), and DuoForce ${ }^{\circledR}$ wires (Figure 3(c)).

In $\mathrm{FLI}^{\circledR}$ arches, a rough surface was observed that was compatible with its Teflon coating (Figure 3(d)). In the afteruse group, flaking of this coating was observed. This resulted in a greater accumulation of substances such as plaque or food on its surface (Figure 3(d)).

In the group that used Gummetal ${ }^{\circledR}$ wires, a rough surface was observed owing to the absence of nickel. Additionally, nonparallel lines that increased in depth were observed in the after-use group. In the same group, dark areas, possibly due to plaque and food debris adhered to the wire, were observed (Figure 3(e)).

A rough surface was evident in the Fantasia ${ }^{\circledR}$ wires afteruse group, with nonparallel lines, cracks, and wells that decreased in the before-use group (Figure 3(f)).

\section{Discussion}

The present study evaluated the biocompatibility of six elastic orthodontic archwires, two of which had aesthetic coating: FLI ${ }^{\circledR}$ wires coated with PTFE and Fantasia ${ }^{\circledR}$ wires coated with rhodium. A cell viability assay was used to evaluate the biocompatibility and cytotoxic behaviour of these new commercially available alloys, using HGF, since they are one of the main oral cells clinically exposed to the potentially toxic effects of orthodontic wires [18].

While performing the cell viability analysis, it was found that the wires without aesthetic coating did not display 


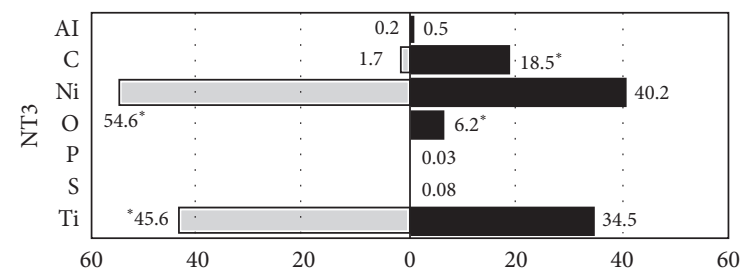

(a)

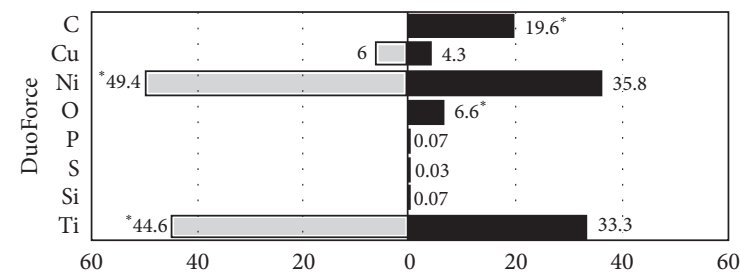

(c)

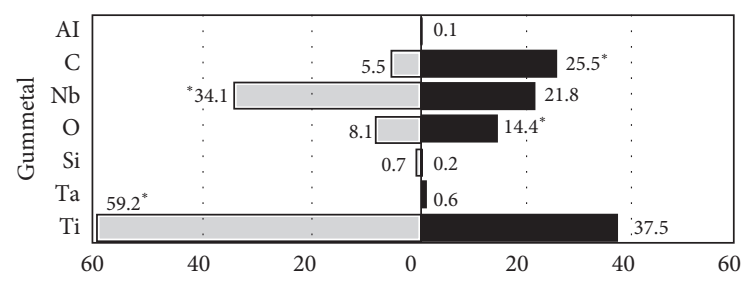

(e)

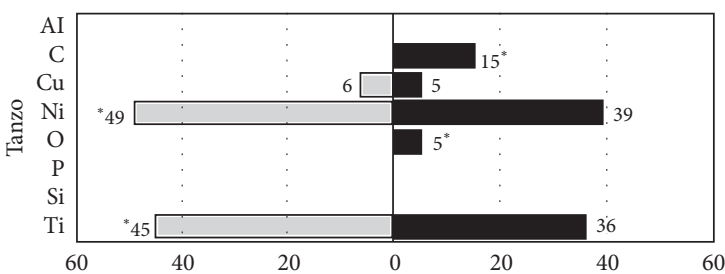

(b)

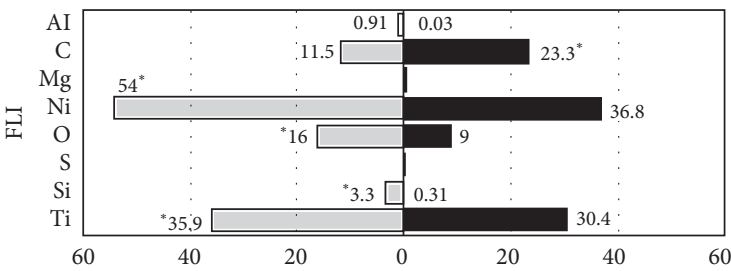

(d)

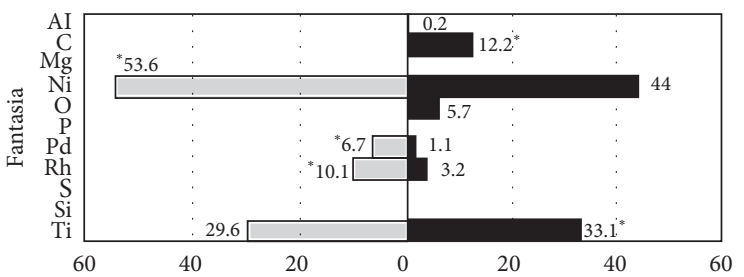

(f)

FIGURE 2: Chemical composition of six wires analysed: in the graphics, observed changes in the elemental composition (\%) of NT3 ${ }^{\circledR}$ (a), Tanzo ${ }^{\circledR}$ (b), DuoForce ${ }^{\circledR}$ (c), FLI ${ }^{\circledR}(\mathrm{d})$, Gummetal $^{\circledR}(\mathrm{e})$, and Fantasia ${ }^{\circledR}$ wires (f) before and after their use in the mouth, ${ }^{*} p \leq 0.05$.

significant changes in the number of viable cells when the wires were compared before and after two months of use.

DuoForce ${ }^{\circledR}$ and Tanzo ${ }^{\circledR}$ wires presented similar cellular viability before and after the wire was used in the mouth. These results are similar to those found by David and Lobner et al. [19], who evaluated the cytotoxicity of nickel-titaniumcopper wires on neuronal and glial cells from mice. Although nickel was present in these arches, they also contained titanium, which is known to decrease the release of metals due to the formation of a passive film, avoiding the generation of toxic effects in cells. The viability of fibroblasts exposed to Gummetal ${ }^{\circledR}$ wires was also not affected. Similar results were obtained by Niinomi et al. [20] while evaluating the cytotoxicity of beta-Ti-Nb-Ta-Zr wires on L929 cells derived from mice after 7 and 14 days. However, Rongo et al. [21] found slight cytotoxicity on days 1 and 7 but no cytotoxicity at 14 days when evaluating beta-titanium wires (TMA).

Additionally, two wires with aesthetic coating were evaluated: FLI ${ }^{\circledR}$, a copper-nickel-titanium wire coated with PTFE, and rhodium-coated Fantasia ${ }^{\circledR}$ wires. On evaluating the cytotoxicity of rhodium-coated wires (Fantasia ${ }^{\circledR}$ ), there were no induced changes in the viability of fibroblasts, as reported earlier [22].

Of the six wires evaluated, only the FLI ${ }^{\circledR}$ wire induced a statistically significant reduction in cell viability by $36 \%$. The reduction in cell viability induced by $\mathrm{FLI}^{\circledR}$ wires corresponds to slight cytotoxicity according to the classification established by Ahrari et al. 2010 [17], and considering the ISO
10993-5 standard [23], for the biological evaluation of medical devices by direct contact, which states that when there is a reduction in cell viability of more than $30 \%$, it is considered to have cytotoxic effects. Rongo et al. [21] determined the cytotoxic effect of several orthodontic wires with and without an aesthetic coating. The authors evaluated NiTi wires coated with Teflon Titanol Cosmetic ${ }^{\circledR}$ from Forestadent and found a slight reduction in the viability of HGF at all analysed times. These results are similar to those of this study, considering that $\mathrm{FLI}^{\circledR}{ }^{\circledR}$ wires also have a coating of PTFE, which progressively wears down with use in the mouth, generating a higher release of ions and a greater accumulation of plaque because of the surface irregularities, as previously reported [24]. Rongo et al. concluded that under experimental conditions, all the NiTi aesthetic archwires resulted in slight cytotoxicity, as did the uncoated wires. As such, their clinical use may have similar risks to uncoated archwires [21].

However, in the present work, the cytotoxic effect of uncoated nickel-titanium (NT3) wires was also evaluated for $72 \mathrm{~h}$, without finding significant alterations in the number of cells during this time. These differences may be related to differences in the methodology and time of cytotoxicity evaluation, since, in Rongo et al., it was evaluated at 1, 7, 14, and 30 days. According to the previous results, aesthetic wires have mild cytotoxicity similar to metal wires, so their clinical use could be considered safe [21].

It is important to note that in vitro cytotoxicity tests do not completely represent the cytotoxic properties of 

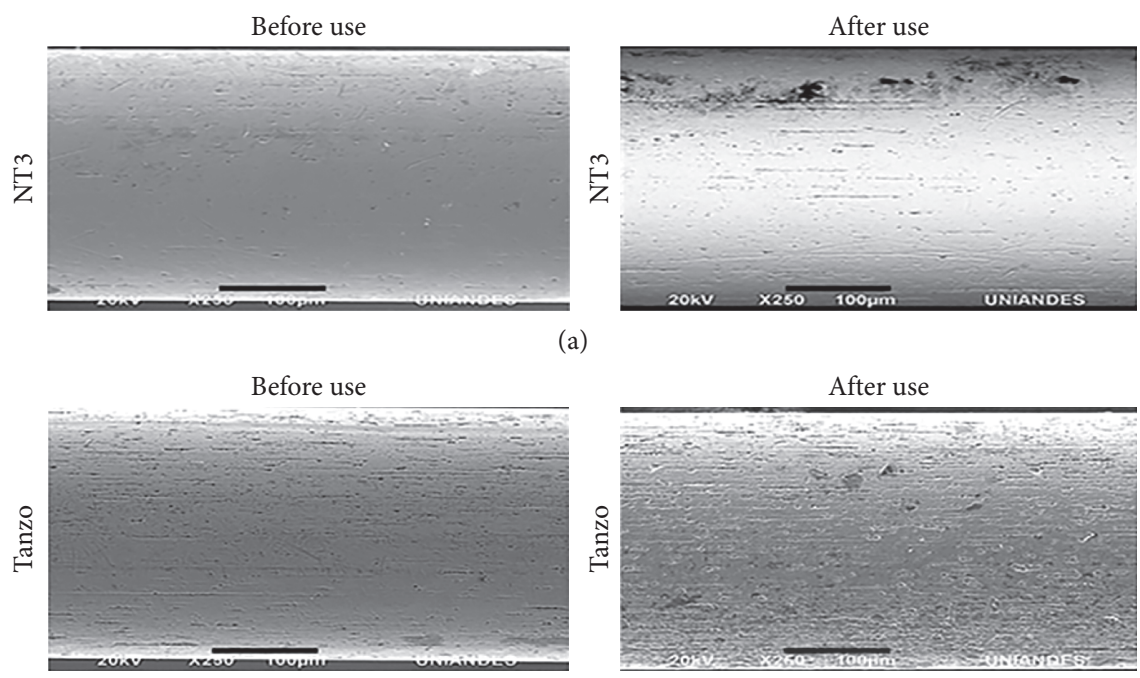

(b)
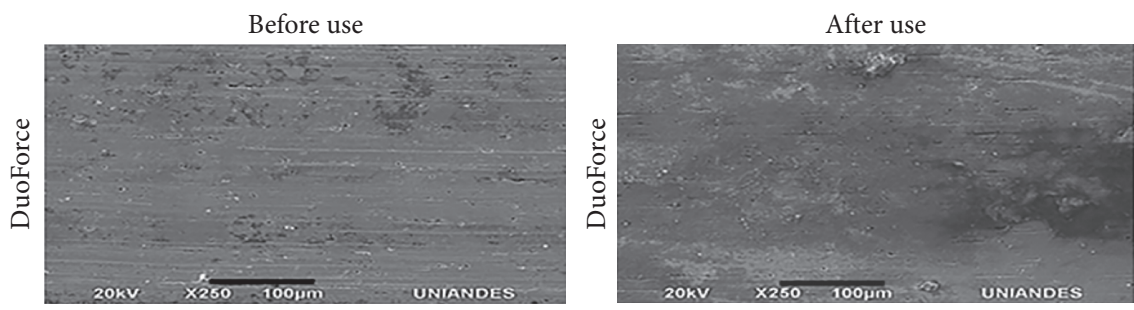

(c)
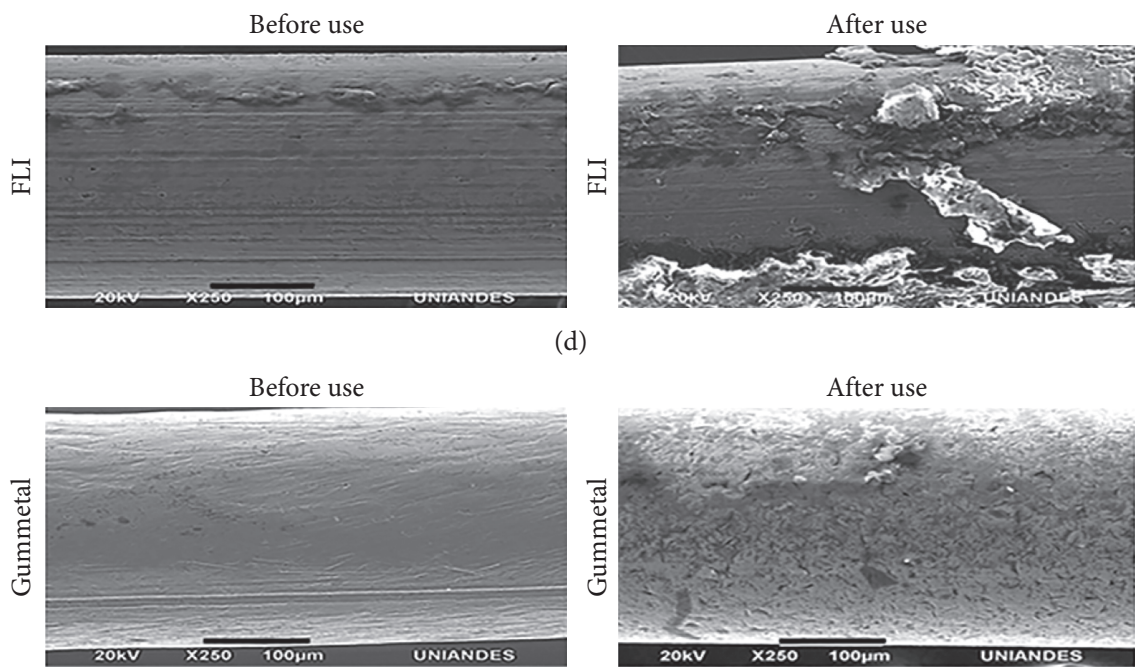

(d)

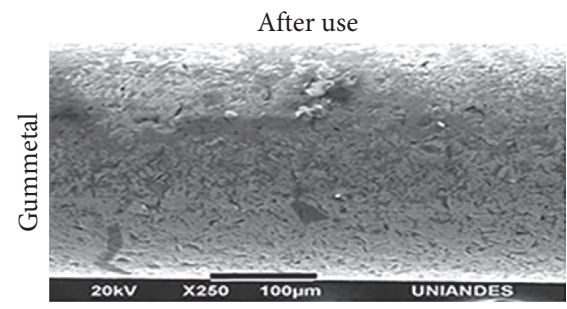

(e)
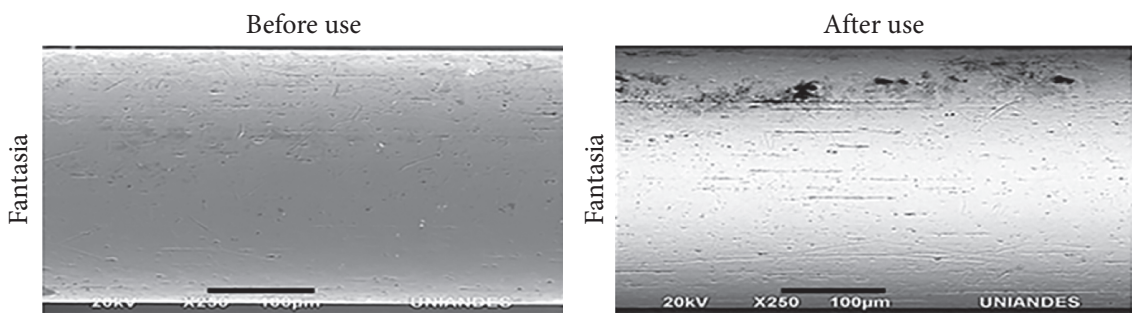

(f)

Figure 3: Scanning microscopy of wires examined: electron microscopy images of NT3 ${ }^{\circledR}$ (a), Tanzo $^{\circledR}$ (b), DuoForce ${ }^{\circledR}$ (c), FLI ${ }^{\circledR}$ (d), Gummetal ${ }^{\circledR}$ (e), and Fantasia ${ }^{\circledR}$ (f) wires before and after use in the mouth. Bar: $100 \mathrm{~mm}$; original magnification: 250x. 
materials in the oral environment. It is known that the oral mucosa is generally more resistant to toxic substances than cell cultures because of the presence of mucin and keratin layers [17]. However, cytotoxicity testing allows a comparison among available products and information for choosing a material with optimal characteristics.

Exposure time is another important parameter in cytotoxicity testing. The direct contact test between the wire and HGF resembles the actual exposure of the cells to the material as it would happen in vivo. However, the evaluation times reported in the literature are short, ranging from 24 to $72 \mathrm{~h}$, as suggested by the ISO10993-5:2009 standard [7] for direct contact cytotoxicity studies. Few studies extend their analysis to more than 3 days $[15,21,25]$ owing to the greater possibility of contamination, cell confluence, costs, and so on. Hence, in this work, a correlation between the cytotoxicity of the material and the evaluation time could not be established.

It is difficult to establish a direct correlation when there is in vitro cytotoxicity, but the use of the wire does cause acute clinical events in vivo. Therefore, the evaluation of subacute symptoms in clinical studies due to the use of this type of wire such as glossitis, metallic taste, bleeding, inflammation, or hypertrophied gingivae previously reported [26] for other materials should not be ruled out.

In this study, in addition to determining the cytotoxic effect, the changes in the chemical composition and surface alterations of the six titanium wires were also evaluated. Cytotoxicity induced by orthodontic appliances is related to the release of metal ions from corrosion processes. The release of substances from a biomaterial, whether from metal ions by corrosion of alloys or degradation of peroxides, can result in adverse effects such as toxicity, allergies, and mutagenicity. Additionally, exposure to ions could limit the recovery time necessary for cell repair [27, 28]. These findings are important as it has been found that degradation of the materials by electrochemical attacks, which are caused by factors such as temperature, quality, and quantity of saliva, bacterial plaque, $\mathrm{pH}$, proteins, and chemical properties of solids and liquids in foods, can initiate the corrosion process and induce cytotoxic effects $[29,30]$. Other studies have shown that a fluoridated and acidic environment such as that produced by creams or dental rinses increases the susceptibility to corrosion of certain metals, especially titanium [31, 32].

When analysing the chemical composition of the six wires studied, a reduction in the percentage of constituent elements after their use in the mouth was generally determined. The biodegradation of wire alloys can cause this reduction because the oral environment induces favourable ionic, thermal, and microbiological changes for the release of ions in the oral cavity [27]. Corrosion can roughen the appliance, increase the friction between archwires and slot, and release metal or alloy ions, which consequently can result in the discoloration of enamel and soft tissues, local pains, and allergic reactions in predisposed patients [33]. Ni and $\mathrm{Cr}$ are considered the most important elements among corrosion products owing to their ability to cause side effects. Corrosion resistance is among the basic principles of biocompatibility and depends on the type of alloy, manufacturing process, and surface features of the materials [34]. The results presented in this work show a significant reduction in the amount of $\mathrm{Ni}$ in the group of wires after its use in the mouth, except in the Gummetal wires that correspond to Ni-free alloys. Nickel is the most common metal that causes contact dermatitis and induces more cases of allergic reactions. The amount of nickel as the main constituent of contemporary orthodontic appliances may vary from $8 \%$ in stainless steel to more than $50 \%$ in NiTi alloys [35]. However, in most of the in vivo studies that have evaluated the liberation of metal ions from orthodontic appliances in biological fluids, it has been concluded that levels of metal ions do not reach the normal daily dietary intake of some elements [2]. Despite this, the possibility remains that even nontoxic concentrations of cations released from dental alloys might be sufficient to produce biological alterations (e.g., in DNA synthesis or alkaline phosphatase activity) [2].

Therefore, corrosion resistance is essential for orthodontic wires, not only because of the cytotoxicity and biological reactions that the released ions can generate but also because this can lead to the roughness of the surface, which severely limits the fatigue life and resistance to material breakage. Some alloys are resistant to corrosion because of their inherent nobility or the formation of a superficial protective layer [36].

$\mathrm{Ti}$ alloys depend on the formation of a passive surface oxide film to resist corrosion. However, even though these protective oxide films are present on the metal surface, metal ions can still be released. Not only is the protective oxide layer susceptible to both mechanical and chemical disruption, but the oxide film can also slowly dissolve as the wire is exposed to oxygen from the surrounding medium [37].

In this work, the appearance of new elements such as oxygen and carbon was observed in all wires, which could be related to the oxidation process of metals. The presence of these elements in the wires after use in the mouth can be caused by the adhesion of food debris, bacterial plaque, and the mechanism of passivation of the metal, where oxygen is taken from the environment as a protective mechanism [28].

When evaluating the morphological changes of the PTFE-coated wires, irregularities were found, and there was a loss of the polymer structure after 2 months of use in the mouth. These results are similar to those obtained in previous studies [38] that reported that the PTFE coating had poor stability because of the thinner coating layer of the asreceived PTFE-coated aesthetic archwires than that reported by the manufacturer. Another study [39] also reported that PTFE-coated archwires showed the highest surface roughness after 28 days of immersion in artificial saliva at a $\mathrm{pH}$ of 6.75 when compared to epoxy resin.

In nickel-titanium $\mathrm{NT}^{\circledR}{ }^{\circledR}$ wires, parallel lines, cracks, and wells were observed in the before-use group. These findings are similar to those reported by Puspitasari et al. [40], where the surface morphology of a superelastic nickel-titanium wire soaked in artificial saliva was found to have fibrous surfaces. In the $\mathrm{NT}^{\circledR}{ }^{\circledR}$ wire group, after use in the mouth, we found dark areas compatible with food debris or bacterial 
plaque that may also be associated with pitting corrosion. This is similar to that reported by Puspitasari et al. [40] in a superelastic nickel-titanium wire that was soaked in artificial saliva. The nickel-titanium-copper wires, Tanzo ${ }^{\circledR}$ and DuoForce ${ }^{\circledR}$, had similar characteristics to the NT3 ${ }^{\circledR}$ wires, with a linear disposition in the arches before being used and higher roughness and indentations after use. In Fantasia ${ }^{\circledR}$ wires, nonparallel lines, cracks, and wells were observed after use in the mouth. Asiry et al. [22] compared epoxy, PTFE, and rhodium coatings and found that epoxy-coated wires had the highest surface roughness values followed by PTFE wires. Rhodium-coated wires were the best-coated wires in terms of surface roughness, comparable to those of uncoated wires. The SEM images showed remarkable changes in the PTFE coating layer on the wires after being used in the mouth. Additionally, the presence of cracks represented the deterioration of the external coating. Previous studies [38] reported that the PTFE coating had poor stability owing to the thinner coating layer. Moreover, this deterioration and coating loss exposes the core metal wire, causing absorption of large amounts of hydrogen because the titanium attracts hydrogen and undesirable aesthetic effects such as discoloration and ruptures that appear when the archwires are used clinically [37]. This results in a gradual change in the mechanical properties that must be considered.

To minimise biological risks, dentists should select alloys that have the highest biocompatibility and the lowest corrosion. The selection of an alloy should be made on a caseby-case basis using corrosion and biological data provided by the manufacturer or obtained in investigations of these new materials. A significant reduction in cell viability was only found in FLI ${ }^{\circledR}$ wires after being used in the mouth, with more evidence of superficial alterations owing to degradation of its coating. Although there were no critical changes in the chemical composition of the wires after being used in the mouth, there was a decrease in the level of all elements and the appearance of other elements, such as oxygen and carbon, possibly related to diet and metal passivation.

Many variables such as wear [41], brushing [42], and biomechanical stresses [43] can alter the metal release of orthodontic wires and the surface of dental materials. Therefore, further studies should examine these variables that cause these changes in wire structures and cytotoxicity, as can be an increasing concentration of metallic ions in the medium over time or a continuous release of substances as a result of the biodegradation of the aesthetic coating. Additionally, the study of factors involved in the loss of the aesthetic coating during wire use is needed.

Within the limitations of this report is the evaluation time of the cytotoxic effect on fibroblasts, which did not allow us to establish whether prolonged exposure of cells to different types of wires can increase cytotoxicity values. On the contrary, changes in the wire composition were determined after the use and deterioration of the aesthetic coating; however, studies must be carried out to establish what factors can cause these changes in wire structures and cytotoxicity. Additionally, clinical studies are necessary to evaluate the metal ion concentrations in patients undergoing orthodontic treatment with these types of archwires, considering variables such as wear, brushing, and biomechanical stress.

\section{Conclusions}

In conclusion, no toxic ion release was observed in this study. Of the six wires evaluated, only one that presented slight cytotoxicity was the FLI ${ }^{\circledR}$ wire. A significant reduction in the percentage of $\mathrm{Ni}$ was observed in all wires after their use, except in the Gummetal ${ }^{\circledR}$ wires. Elements $\mathrm{C}$ and $\mathrm{O}$ appeared on the wires after two months of use. Rhodiumcoated wires were more stable after use than PTFE-coated wires. PTFE-coated wires showed greater irregularities and loss of polymer structure after two months of use in the mouth.

\section{Data Availability}

The data used to support the findings of this study are available from the corresponding author upon request.

\section{Conflicts of Interest}

The authors declare no conflicts of interest.

\section{References}

[1] A. Mirhashemi, S. Jahangiri, and M. Kharrazifard, "Release of nickel and chromium ions from orthodontic wires following the use of teeth whitening mouthwashes," Progress in Orthodontics, vol. 19, no. 1, p. 4, 2018.

[2] D. Quadras, U. K. Nayak, N. Kumari, H. Priyadarshini, S. Gowda, and B. Fernandes, "In vivo study on the release of nickel, chromium, and zinc in saliva and serum from patients treated with fixed orthodontic appliances," Dental Research Journal, vol. 16, no. 4, pp. 209-215, 2019.

[3] B. Wendl, H. Wiltsche, E. Lankmayr et al., "Metal release profiles of orthodontic bands, brackets, and wires: an in vitro study," Journal of Orofacial Orthopedics/Fortschritte der Kieferorthopädie, vol. 78, no. 6, pp. 494-503, 2017.

[4] J. C. Wataha, "Biocompatibility of dental casting alloys: a review," The Journal of Prosthetic Dentistry, vol. 83, no. 2, pp. 223-234, 2000.

[5] J. Bącela, M. B. Łabowska, J. Detyna, A. Zięty, and I. Michalak, "Functional coatings for orthodontic archwires-A review," Materials, vol. 13, no. 15, p. 3257, 2020.

[6] A. M. Saglam, V. Baysal, and A. M. Ceylan, "Nickel and cobalt hypersensitivity reaction before and after orthodontic therapy in children," The Journal of Contemporary Dental Practice, vol. 5, no. 4, pp. 79-90, 2004.

[7] A. Martín-Cameán, Á. Jos, P. Mellado-García, A. IglesiasLinares, E. Solano, and A. M. Cameán, "In vitro and in vivo evidence of the cytotoxic and genotoxic effects of metal ions released by orthodontic appliances: a review," Environmental Toxicology and Pharmacology, vol. 40, no. 1, pp. 86-113, 2015.

[8] L. S. Jacoby, V. D. S. Rodrigues, M. M. Campos, and L. Macedo De Menezes, "Cytotoxic outcomes of orthodontic bands with and without silver solder in different cell lineages," American Journal of Orthodontics and Dentofacial Orthopedics, vol. 151, no. 5, pp. 957-963, 2017.

[9] H.-P. Chang and Y.-C. Tseng, "A novel $\beta$-titanium alloy orthodontic wire," The Kaohsiung Journal of Medical Sciences, vol. 34, no. 4, pp. 202-206, 2018. 
[10] E. Atik, H. Gorucu-Coskuner, B. Akarsu-Guven, and T. Taner, "A comparative assessment of clinical efficiency between premium heat-activated copper nickel-titanium and superelastic nickel-titanium archwires during initial orthodontic alignment in adolescents: a randomized clinical trial," Progress in Orthodontics, vol. 20, no. 1, p. 46, 2019.

[11] T. P. Furlan, J. A. Barbosa, and R. T. Basting, "Nickel, copper, and chromium release by CuNi-titanium orthodontic archwires is dependent on the $\mathrm{pH}$ media," Journal of International Oral Health, vol. 10, no. 5, pp. 224-228, 2018.

[12] L. Friedli, P. Nalabothu, C. Bosch, C. Verna, M. Steineck, and M. Dalstra, "Influence of different storage temperatures on the mechanical properties of NiTi, Cu-NiTi and SS orthodontic archwires: an in vitro study," International Orthodontics, vol. 18, no. 3, pp. 561-568, 2020.

[13] T. G. Bradley, D. W. Berzins, N. Valeri, J. Pruszynski, T. Eliades, and C. Katsaros, "An investigation into the mechanical and aesthetic properties of new generation coated nickel-titanium wires in the as-received state and after clinical use," European Journal of Orthodontics, vol. 36, no. 3, pp. 290-296, 2014.

[14] A. A. Kaphoor and S. Sundareswaran, "Aesthetic nickel titanium wires--how much do they deliver?" The European Journal of Orthodontics, vol. 34, no. 5, pp. 603-609, 2012.

[15] E. Toy, S. Malkoc, B. Corekci, B. S. Bozkurt, and S. S. Hakki, "Real-time cell analysis of the cytotoxicity of orthodontic brackets on gingival fibroblasts," Journal of Applied Biomaterials \& Functional Materials, vol. 12, no. 3, pp. 248-255, 2014.

[16] M. I. A. Pereira, C. A. P. Monteiro, W. F. De Oliveira, B. S. Santos, A. Fontes, and P. E. Cabral Filho, "Resazurinbased assay to evaluate cell viability after quantum dot interaction," Quantum Dots, vol. 2135, pp. 213-221, 2020.

[17] F. Ahrari, J. Tavakkol Afshari, M. Poosti, and A. Brook, "Cytotoxicity of orthodontic bonding adhesive resins on human oral fibroblasts," The European Journal of Orthodontics, vol. 32, no. 6, pp. 688-692, 2010.

[18] S. Martina, R. Rongo, R. Bucci, A. V. Razionale, R. Valletta, and V. D'Antò, "In vitro cytotoxicity of different thermoplastic materials for clear aligners," The Angle Orthodontist, vol. 89, no. 6, pp. 942-945, 2019.

[19] A. David and D. Lobner, "In vitro cytotoxicity of orthodontic archwires in cortical cell cultures," The European Journal of Orthodontics, vol. 26, no. 4, pp. 421-426, 2004.

[20] M. Niinomi, "Fatigue performance and cyto-toxicity of low rigidity titanium alloy, Ti-29Nb-13Ta-4.6Zr," Biomaterials, vol. 24, no. 16, pp. 2673-2683, 2003.

[21] R. Rongo, R. Valletta, R. Bucci et al., "In vitro biocompatibility of nickel-titanium esthetic orthodontic archwires," The Angle Orthodontist, vol. 86, no. 5, pp. 789-795, 2016.

[22] M. A. Asiry, I. AlShahrani, S. Almoammar, B. H. Durgesh, A. A. Kheraif, and M. I. Hashem, "Influence of epoxy, polytetrafluoroethylene (PTFE) and rhodium surface coatings on surface roughness, nano-mechanical properties and biofilm adhesion of nickel titanium (Ni-Ti) archwires," Materials Research Express, vol. 5, no. 2, pp. 1-7, 2018.

[23] G. Sjögren, G. Sletten, and J. E. Dahl, "Cytotoxicity of dental alloys, metals, and ceramics assessed by millipore filter, agar overlay, and MTT tests," The Journal of Prosthetic Dentistry, vol. 84, no. 2, pp. 229-236, 2000.

[24] C. G. D. Albuquerque, A. B. Correr, G. C. Venezian, M. Santamaria, C. A. Tubel, and S. A. S. Vedovello, "Deflection and flexural strength effects on the roughness of aesthetic-coated orthodontic wires," Brazilian Dental Journal, vol. 28, no. 1, pp. 40-45, 2017.

[25] A. J. Ortiz, E. Fernandez, A. Vicente, J. L. Calvo, and C. Ortiz, "Metallic ions released from stainless steel, nickel-free, and titanium orthodontic alloys: toxicity and DNA damage," American Journal of Orthodontics and Dentofacial Orthopedics, vol. 140, no. 3, pp. 115-122, 2011.

[26] O. Mockers, D. Deroze, and J. Camps, "Cytotoxicity of orthodontic bands, brackets and archwires in vitro," Dental Materials, vol. 18, no. 4, pp. 311-317, 2002.

[27] S. M. Castro, M. J. Ponces, J. D. Lopes, M. Vasconcelos, and M. C. F. Pollmann, "Orthodontic wires and its corrosion-The specific case of stainless steel and beta-titanium," Journal of Dental Sciences, vol. 10, no. 1, pp. 1-7, 2015.

[28] I. Sifakakis and T. Eliades, "Adverse reactions to orthodontic materials," Australian Dental Journal, vol. 62, no. Suppl 1, pp. 20-28, 2017.

[29] S. Noumbissi, A. Scarano, and S. A. Gupta, "Literature Review Study on Atomic Ions Dissolution of Titanium and Its Alloys in Implant Dentistry," Materials, vol. 12, no. 3, p. 368, 2019.

[30] T. Chaturvedi, "An overview of the corrosion aspect of dental implants (titanium and its alloys," Indian Journal of Dental Research, vol. 20, no. 1, pp. 91-98, 2009.

[31] K. House, F. Sernetz, D. Dymock, J. R. Sandy, and A. J. Ireland, "Corrosion of orthodontic appliances-should we care?" American Journal of Orthodontics and Dentofacial Orthopedics, vol. 133, no. 4, pp. 584-592, 2008.

[32] M. Rincic Mlinaric, S. Karlovic, Z. Ciganj, D. P. Acev, A. Pavlic, and S. Spalj, "Oral antiseptics and nickel-titanium alloys: mechanical and chemical effects of interaction," Odontology, vol. 107, no. 2, pp. 150-157, 2019.

[33] S. Tahmasbi, T. Sheikh, and Y. B. Hemmati, "Ion release and galvanic corrosion of different orthodontic brackets and wires in artificial saliva," The Journal of Contemporary Dental Practice, vol. 18, no. 3, pp. 222-227, 2017.

[34] V. Katić, H. O. Curković, D. Semenski, G. Baršić, K. Marušić, and S. Spalj, "Influence of surface layer on mechanical and corrosion properties of nickel-titanium orthodontic wires," The Angle Orthodontist, vol. 84, no. 6, pp. 1041-1048, 2014.

[35] M. Imani, H. Mozaffari, M. Ramezani, and M. Sadeghi, "Effect of fixed orthodontic treatment on salivary nickel and chromium levels: a systematic review and meta-analysis of observational studies," Dentistry Journal, vol. 7, no. 1, p. 21, 2019.

[36] N. Eliaz, "Corrosion of metallic biomaterials: a review," Materials, vol. 12, no. 3, p. 407, 2019.

[37] Y. C. Abdulkader, A. F. Kamaruddin, and R. B. S. M. N. Mydin, "Effects of salivary $\mathrm{pH}$ on coating durability of two different aesthetic archwire coatings under a simulated intraoral environment," The Saudi Dental Journal, vol. 32, no. 6, pp. 306-313, 2020.

[38] N. Argalji, E. M. D. Silva, A. Cury-Saramago, and C. T. Mattos, "Characterization and coating stability evaluation of nickel-titanium orthodontic esthetic wires: an in vivo study," Brazilian Oral Research, vol. 31, p. e68, 2017.

[39] N. S. Muayad and N. H. Ghaib, "The effect of artificial saliva on the surface roughness of different esthetic archwires: an in vitro study," Journal of Baghdad College of Dentistry, vol. 29, no. 3, pp. 106-112, 2017.

[40] Y. Puspitasari, "THe difference of surface morphology and chemical composition of superelastic nickel titanium orthodontic wires before and after in artificial saliva submersion," Dentino, vol. 2, no. 2, pp. 160-165, 2017. 
[41] S. Jin, J.-W. Choi, C.-M. Jeong et al., "Evaluating the wear of resin teeth by different opposing restorative materials," Materials, vol. 12, no. 22, p. 3684, 2019.

[42] A. Scribante, P. Vallittu, L. V. J. Lassila et al., "Effect of long-term brushing on deflection, maximum load, and wear of stainless steel wires and conventional and spot bonded fiber-reinforced composites," International Journal of Molecular Sciences, vol. 20, no. 23, p. 6043, 2019.

[43] O. Komiyama, F. Lobbezoo, A. De Laat et al., "Clinical management of implant prostheses in patients with bruxism," International Journal of Biomaterials, vol. 2012, Article ID 369063, 16 pages, 2012. 